\title{
Primary neuritic leprosy in a black South African
}

\author{
N A MAFOYANE*, W K JACYK $† \ddagger \&$ B P LOTZ* \\ Departments of Neurology* and Dermatology $\dagger$, Kalafong Hospital, \\ Private Bag X396, 001 Pretoria, Republic of South Africa
}

\author{
Accepted for publication 1 May 1992
}

\begin{abstract}
Summary A case of primary neuritic leprosy in a black South African is described, in which the multiple peripheral nerves were affected. The clinical picture and electrophysiological studies are in keeping with a picture of mononeuritis multiplex. Selective involvement of the facial nerve branches with normal blink reflex latencies was observed. The biopsy of the sural nerve disclosed features most consistent with borderline leprosy.
\end{abstract}

\section{Introduction}

Cases of primary neuritic leprosy in which no skin lesions of leprosy develop are not infrequent on the Indian subcontinent. In reports from other parts of the world patients with this form of leprosy were either Indians or Pakistanis. ${ }^{1-6}$ Hargrave \& Marion ${ }^{7}$ described primary polyneuritic leprosy in an Australian aboriginal. Here we describe a black South African male with polyneuritic leprosy.

\section{Case report}

A 37-year-old black male was admitted to Kalafong Hospital in November 1989. He gave an 18-month history of pain in both hands followed by weakness and loss of sensation. $\mathrm{He}$ had no relevant past medical history. He denied ever having skin lesions. He seemed familiar with cutaneous manifestations of leprosy because his sister and father suffered from leprosy.

The significant physical findings were:

a. Bilateral fusiform thickening of the following nerves: the posterior auricular nerves, the ulnar nerves, the radial cutaneous nerves with the left much thicker than the right,

$\ddagger$ Correspondence.

0305-7518/92/063274+05\$01.00 (C) Lepra 
the common peroneal nerves and the sural nerves. All thickened nerves were firm and nontender.

b. Bilateral lower motor neurone facial paresis of moderate severity affecting mainly the temporal and zygomatic branches which resulted in the inability to close his eyes.

c. Both his hands showed atrophy of the thenar and hypothenar muscles, the interosseous muscles and claw hand deformities. All hand muscles were weak bilaterally.

d. He had a glove and stocking distribution of spinothalamic loss but normal position and vibration sense. He had loss of the distal phalanx of his right big toe and he walked with bilateral footdrop. The clinical picture in the lower limbs was consistent with damage to the common peroneal nerves and posterior tibial nerves bilaterally.

The rest of his neurological system and the systemic examination were normal. There were no skin lesions of leprosy and there was no loss of eyebrows and eyelashes. The results of specal investigations were as follows:

\section{NEUROPHYSIOLOGICAL TESTS}

Nerve conduction. Both median nerves showed abnormally slow motor conduction velocities and low compound motor action potentials. No response was elicited on stimulation of the left ulnar nerve (motor), left posterior tibial nerve (motor) and the right radial nerve (sensory).

Blink reflexes were obtained stimulating the supraorbital nerves and recording from the orbicularis oculi muscles. The right and left blink reflexes were normal.

Needle examination. Needle examination of the right vastus lateralis, right pronator teres and right paraspinal muscles was normal. Needle examination of the following muscles showed signs of denervation (fibrillation potentials and/or long duration motor unit potentials): right tibialis anterior, right gastrocnemius, right abductor hallucis, right first dorsal interosseus and right abductor pollicis brevis.

These neurophysiological tests implied total axonal degeneration in those nerves from which no response could be elicited and a combination of demyelination and axonal damage in the extremity nerves from which response could be obtained.

\section{SKIN-SPLIT SMEARS}

Smears' taken from 6 standard sites were all negative.

3. NERVE BIOPSY (left sural nerve) (Figures 1 and 2).

There was a chronic granulomatous infiltrate in the nerve bundles and perineurium as well as extensive destruction of nerves and fibrosis. The infiltrate consisted of epithelioid cell, lymphocytes and scanty giant cells, more of foreign body than Langhans type. A few broken acid- and alcohol-fast organisms were seen on special stain. 


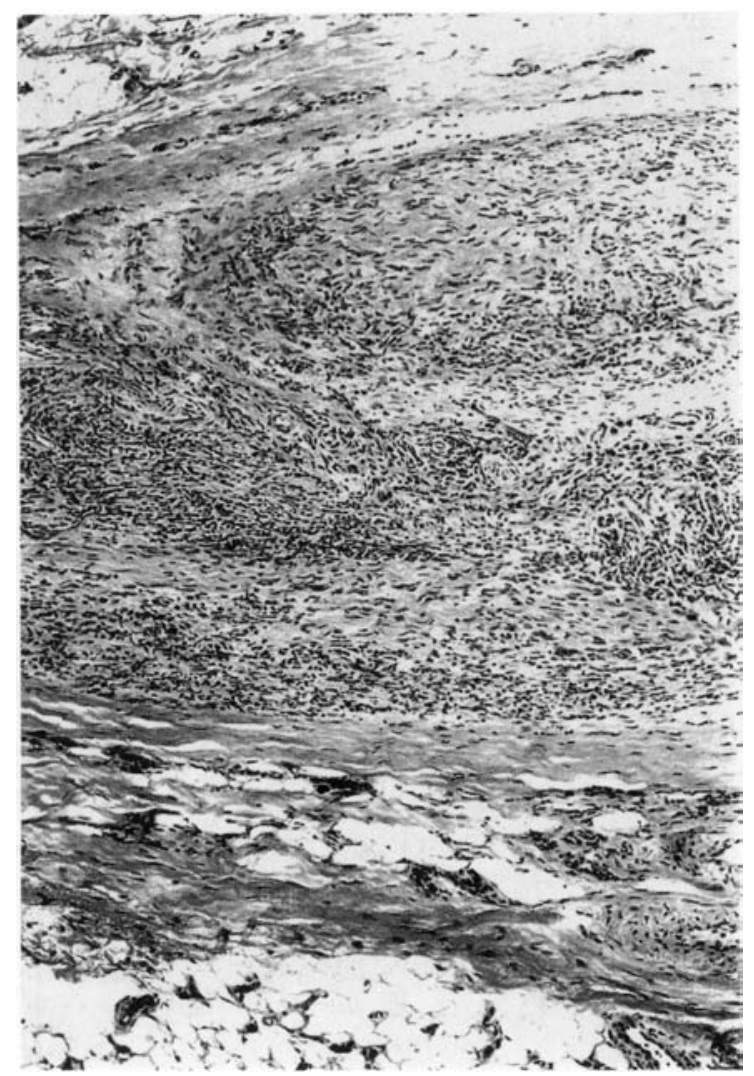

Figure 1. Granulomatous infiltrate in peripheral nerve bundles. $\mathrm{H} \& \mathrm{E} \times 80$.

\section{OTHER TESTS}

The following tests were normal or negative:

Full blood count, tests for syphilis in serum and cerebrospinal fluid, serum glucose, SMA II, lumbar puncture including pressure and chemistry, chest x-rays and the electrocardiogram.

\section{Discussion}

An epidemiological study conducted by Noordeen ${ }^{8}$ showed the neuritic form to constitute $17.7 \%$ of all types of leprosy seen in Chingleput District, Tamil Nadu State, India. In Africa a neuritic form of leprosy seems to occur much less frequently. To our knowledge primary neuritic leprosy has not been so far reported in a black Af rican. According to R E Pfalzgraff (personal communication) neuritic leprosy occurs in Africa but it constitutes less than $1 \%$ of cases. The extent of nerve damage in our patient with involvement of all 4 limbs and 14 nerves affected is very unusual, as most patients with a neuritic form show 


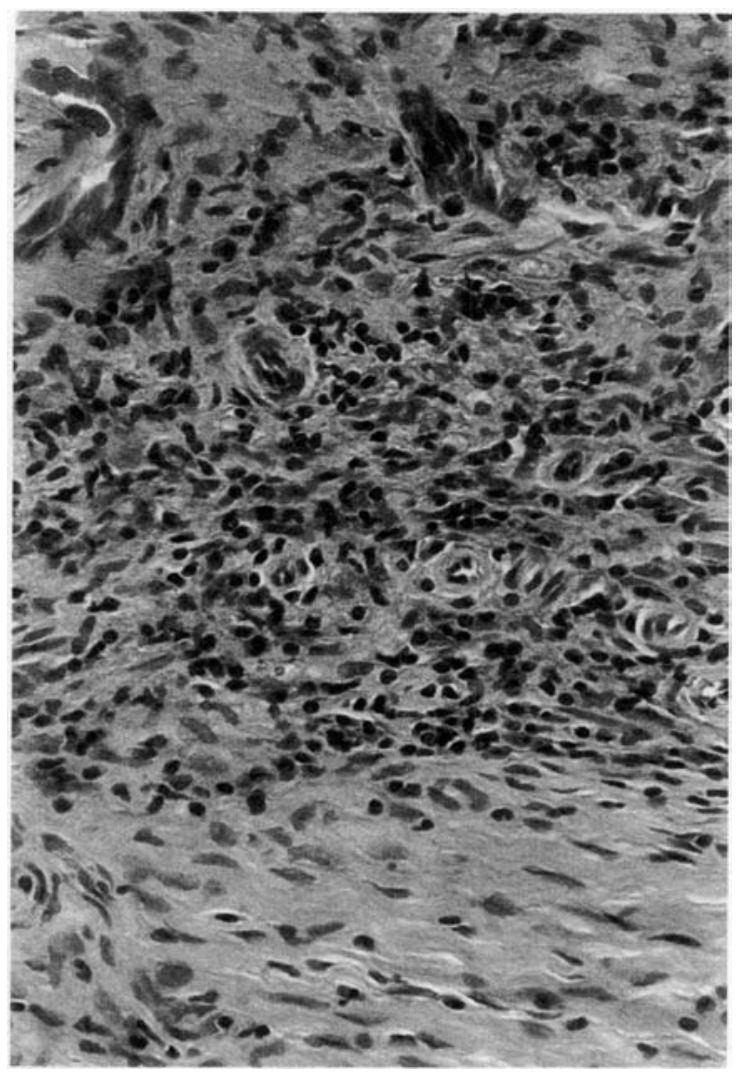

Figure 2. A detail of the granuloma showing central epithelioid cells with peripheral lymphocytes and fibrosis. $\mathrm{H} \& \mathrm{E} \times 160$.

rather mild symptoms. Histological classification of the case appears difficult. Granulomatous changes with numerous epithelioid cells and a mixture of lymphocytes would suggest a BT type, whereas partial preservation of peripheral nerves, the foamy nature of some macrophages and the presence of acid-fast debris are in favour of him being a BB or BL type. The large number of involved nerves would also point toward borderlinelepromatous type.

Kaur et al. ${ }^{9}$ have demonstrated, however, that in neuritic leprosy the number of affected nerves, the nerve pathology and immune response are not interrelated.

Hereditary motor sénsory neuropathy type I and III are diseases that most closely resemble primary neuritic leprosy. The age and mode of onset, the preservation of vibration and positional sense and the normal cerebrospinalfluid proteins are factors against the diagnosis of hereditary neuropathies. The normal blink reflexes were surprising in view of the clinical evidence of peripheral facial nerve involvement. This would imply that the process was mainly axonal and/or that the facial nerve involvement in neuritic leprosy can be highly focal and that specific peripheral branches of the facial nerve can be affected in isolation. 


\title{
Acknowledgments
}

We wish to thank Dr L S de Haas for help in assessment of the histopathology of the nerve biopsy.

\section{References}

1 Jopling WH. Borderline (dimorphous) leprosy manifesting a polyneuritic form for 8 years. A case report. Trans Roy Soc Trop Med Hyg, 1956; 56: 478-80.

2 Jopling WH, Morgan-Hughes JA. Pure neural tuberculoid leprosy. Brit Med J, 1965; 2: 799-800.

3 Hoare JR. Solitary neural tuberculoid leprosy. Proc Roy Soc Med, 1968; 61: 672.

4 Finkelstein S, Sima AA, Lougheed WM, Gentili F, Keystone JA. Pure neural tuberculoid leprosy simulating a peripheral nerve tumor. Neurosurgery, 1982; 10: 771-4.

5 Lao IO, Waldman G, Bronson DM, Barsky S. Pure neural leprosy diagnosed in the United States. Int $J$ Dermat, 1985; 24: 318-19.

6 Vieregge P, Reinhardt V, Gerhardt L, Schliwinski U, Jörg JR. Untreated borderline leprosy in the ulnar nerve: Light and electron microscopy studies. Lepr Rev, 1985; 56: 5-16.

${ }^{7}$ Hargrave JC, Mother Marion. Leprotic involvement of multiple peripheral nerves in the absence of skin lesions. Lepr Rev, 1964; 35: 78-82.

8 Noordeen SK. Epidemiology of (Poly)neuritic type of leprosy. Lepr India, 1972; 44: 90-96.

${ }^{9}$ Kaur G, Girdhar BK, Girdhar A, Malaviya GN, Muckerjee A, Sengupta U, Desikan KV. A clinical, immunological, and histological study of neuritic leprosy patients. Int J Lepr, 1991; 59: 385-91.

Lepr Rev (1992) 63, 277-281

\section{Lèpre névritique primaire chez un Noir d'Afrique du Sud}

\author{
N A Mafoyane, W K Jacyk et B P Lotz
}

Resumé Nous décrivons un cas de lèpre névritique primaire chez un noir d'Afrique du Sud, où plusieurs nerfs périphériques étaient atteints. Le tableau clinique et les observations électrophysiologiques évoquent la mononévrite multiple. Nous avons observé l'implication sélective des branches du nerf facial avec latences normales du reflexe de clignement des paupières. La biopsie du nerf saphène a présenté des signes très compatibles avec une lèpre borderline.

\section{La Lepra Neurítica Primaria en un Sudafricano Negro}

\author{
N A Mafoyane, W K JaCyK y B P Lotz
}

Resumen Se describe un caso de lepra neurítica primaria (un sudafricano negro) en que estaban afectados nervios periféricos múltiples. El cuadro clínico y los estudios electro-fisiológicos son consistentes con un caso de mononeuritis multiplex. Se observó una implicación selectiva de las ramas de los nervios faciales con latencias del reflejo de parpadeo normales. La biopsia del nervio sural reveló características que eran principalmente consistentes con una lepra incierta. 